BY ROBERT VOSPER

\title{
There Is No End
}

$\mathrm{O}^{\mathrm{s}}$

F THE MAKING OF BOOKS there is no end," saith the Preacher in Ecclesiastes, and we can rightly paraphrase him with: "Of the collecting of books there is no end." the phrase is right, but the spirit is wrong. To this phrase, to both these phrases, I would react, and have you react, not with the Preacher's pessimism; we should respond instead with a fervent "Hallelujah!" for in the endless production and supply of books, and in the endless quest to collect them, there is full evidence of the endless vitality and curiosity of men's minds.

I have been asked to say something about "Building a Scholarly Library," but Mr. Frank K. Walter should have been doing this instead of me. As a matter of fact, he has done so already in the most pragmatic and dramatic style by building one, book by book and book crate by book crate, right here before your eyes.

Scholarly libraries, like the universities they serve, are variegated, many-faceted institutions. University librarians, like university presidents, cannot evenly achieve distinction in all aspects of their multiform, almost quixotic, responsibilities: some can attract and retain a superb staff, some can initiate into the mysteries of classification, some are adept at architecture or at management. But that university is doomed, should it want a distinguished library, which does not have somewhere in its recent history a librarian hag-ridden by the need for books

$M r$. Vosper is Director, University of Kansas Libraries. This paper was presented as a Frank $K$. Walter Lecture at the University of Minnesota May 8, 1959. and endowed with the skills to acquire them.

Minnesota is favored in that Mr. Walter was such a librarian; he in turn was favored in serving a university that fully appreciates the uncommon and beneficent support he gave to the university's search for academic distinction. During his incumbency, I am told, almost a million volumes were added to the collections; and his two buying trips to Europe in the 1930's alone netted over 200,000 volumes - a remarkable achievement indeed. Through his persistent efforts a solid stratum was laid down, consisting of the proceedings of learned societies and academies, serial publications and newspapers, and the official publications of foreign governments, especially those of Northern Europe and the Baltic countries. This, in fact, is how to build a scholarly library, so there is actually little more for me to relate.

What I shall try to do then, in order appropriately to fill in this evening's program, is to generalize a bit, with a slight historical bent, on the quest for library books. I shall emphasize the massive quest, the safari approach, the dramatic en bloc accession, rather than the equally important, more patient and precise, method of selecting and searching out individual books.

I will hope to remind you that the quest for books is indeed endless, that the opportunity and the need have not ceased, and that the passion and the pattern for building scholarly libraries have changed but little since the quest first began. Most particularly I will hope to dispel any sense of the Preacher's pessimism that may linger. For I have been amazed in recent years at the number of librarians and university presidents who 
wail over the endless growth of library collections and waste their energy in a search for limiting factors, for hedges and dams against growth. These prophets of doom see nothing but the "problems of libraries" and rising costs, as though, after all these years, they are suddenly endowed with the wisdom to know the millenium where we can in conscience stop adding books. They are infected with "weariness of the flesh." I will hope to suggest that this growth has always been with us, at least in times of intellectual vitality, and that the hopeful lesson of history proposes that the quest for books will continue, as an essential function of civilization and as the librarian's major responsibility.

The quest began, perhaps, in Athens, in a period of high intellectual curiosity and creativity. At least Strabo reports: "Aristotle bequeathed his own library to Theophrastus, to whom he also left his school; and he is the first man," so far as Strabo knows, "to have collected books and to have taught the Kings of Egypt how to arrange a library." That the Kings of Egypt learned well, we know from many accounts. Most recently, George Sarton in the posthumous second volume of his projected History of Science, makes this judgment:

The Museum [at Alexandria] was the center of scientific research; the Library attached to it was the memory of the scientific departments of the Museum. The physicians needed the works of Hippocrates and other predecessors; the astronomers needed the records of early observations and theories. In the case of the humanities the Library did not simply provide information, it contained the very masterpieces. The anatomist might find books in the Library, but not bodies; the astronomers might find books, but not the stars nor the glory of heaven. On the other hand, if the humanist wanted to read the Iliad or the Odyssey, the songs of Anacreon or the odes of Simonides, those very treasures would be available to him in the Library and perhaps nowhere else. The Library was the very heart of the humanities. . . . The Library of Alexandria was really a new start as much as was the Museum.

How was that first great scholarly library built, and in what spirit? According to Moses Hadas, the oldest of our notices is in Aristeas to Philocrates:

When Demetrius of Phalerum was put in charge of the king's library, he was assigned large sums of money with a view to collecting, if possible, all the books in the world; and by arranging purchases and transcriptions, he carried the king's design to completion as far as he was able. When he was asked, in my presence, about how many thousands of books were already collected, he replied, "Above two hundred thousand, Your Majesty; and in a short while I shall exert every effort for the remainder, to round out the number of half a million. I am informed that the laws of the Jews also are worthy of transcription and of being included in your library."

"What is to prevent you from doing so?" the king replied; "All the necessary means are at your disposal."

But Demetrius said, "Translation is required; in the country of the Jews they use a peculiar script ... and they have their own language."

This was in the second or third century B.c. Now in 1959 I merely remind you of how modern this sounds. Just a few years ago some scholarly libraries in this country had hopes of "collecting, if possible, all the books in the world." Today, collectively through the Farmington Plan, we make the same proud boast, and today our boast is tempered a bit by the continuing problem of translation, but our problem is with Swahili and Urdu rather than with the "peculiar script" of the Jews.

The next efflorescence we should recall is that of the late fourteenth and early fifteenth centuries in Italy. As John Addington Symonds has said, "The first step toward the revival of learning im- 
plied three things: first, the collection of MSS wherever they could be saved from the indolence of the monks; secondly, the formation of libraries for their preservation; and, thirdly, the invention of an art whereby they might be multiplied cheaply, conveniently, and accurately." Here again the zest for learning and humanistic creativity are intimately tied up with the endless quest for books. The eager personal adventures of Petrarch and Boccaccio in recovering and transcribing Latin manuscripts are well known, but the career of Poggio Bracciolini at the opening of the fifteenth century exemplifies the eternal passion and drive to accumulate scholarly libraries. Branching out from Constance where he went as a Papal secretary, Poggio made four expeditions between 1415 and 1417 to Cluny, St. Gall, and to other monasteries in France and Germany, in search of manuscripts that he might transcribe or actually bear away. J. E. Sandys paraphrases Poggio's December 1416 letter to Guarini as follows: "So eager was the quest that even the wretched condition of the roads did not prevent Poggio and [his companions] from sallying forth from Constance and climbing the steep slopes that led to St. Gallen some twenty miles distant. In that ancient home of learning they found the abbot and the monks absolutely uninterested in literature, and many a precious MS lying amidst the dust and damp and darkness of one of the towers of the abbey-church, a noisome building (says Poggio) to which even criminals condemned to death would never have been confined."

Subsequent expeditions drew Poggio himself as far afield as England, a cold and barbaric land in that day; his friends and emissaries hunted manuscripts for him in Portugal and in Scandinavia. In snow and in summer heat, to the clear detriment of his purse and his health, he continued the quest for books throughout his life. As a result of his efforts, the world of Renaissance learning came to know such writers as Cicero, Quintillian, Lucretius, Petronius, and much of Plautus; and the Laurentian, the Medicean, and other Italian libraries were greatly enriched.

Other manuscript hunters later in the fifteenth century turned eastward and brought Greek learning to Italy once more. One of the most successful, John Lascaris, was twice commissioned by Lorenzo de' Medici to undertake expeditions to the East for the Medicean Library. The second journey, at the end of the fifteenth century, lasted two years and recovered as many as 200 manuscripts from Mount Athos. Lascaris' notebook listing desiderata for that venture is still extant.

The lure of the manuscript riches of the Eastern monasteries is a nice symbol of the persistent quest for books. The Alexandrian librarians had searched for the writings of the Jews in this region many centuries before Lascaris, and we can wonder romantically whether they knew of the manuscript hoards so recently discovered at Qumran on the shores of the Dead Sea. Lascaris in turn was followed by many other adventurous book hunters over the centuries. The British Museum manuscript collections were strengthened by 200 items through the efforts of Robert Curzon, a nineteenth century Poggio or John Lascaris, touched with the same joy of exploration. In the 1830's, when travel in these areas was hardly less difficult than in the fifteenth century, Curzon went to Egypt, the Levant, and the Holy Land, and to Greece in search of rare oriental manuscripts. By camel he traveled northwest of Cairo to visit the ancient Coptic monasteries in the Desert of Nitria, battling the heat and ravenous fleas. At Souriani he found superb Coptic manuscripts of the Gospels, with commentaries by the early fathers of the church, "doing duty as coverings to a couple of large open pots or jars, which had contained pre- 
serves, long since evaporated." The monks let him purchase these vellum manuscripts "as they were considered to be useless by the monks, principally ... because there were no more preserves in the jars." The custodians, however, were less eager to allow him access to their oil-cellar where other manuscripts were said to be stored, but by the deft application of a bottle of rosolio wine and the promise of more, he soon won their good will. The main cellar revealed nothing but empty casks, until Curzon "discovered a narrow low door, and, pushing it open, entered into a small closet vaulted with stone which was filled to a depth of two feet or more with the loose leaves of the Syriac manuscripts which now form one of the chief treasures of the British Museum." How reminiscent this is of Poggio at St. Gall three centuries earlier.

Toward the end of his travels he came to the Monastery of Pantocratoras on Mount Athos and was told that the library, in the great square tower, had been destroyed during the revolution. He peered in through the arch: "It was indeed a heart-rending sight. By the dim light ... I saw about a hundred ancient manuscripts lying among the rubbish." The monks warned him away because the floor had fallen in and the beams were rotten from the rain. But Curzon crept along the wall of this "trap ready set and baited for a bibliographical antiquary" and with a stick fished out a few of the largest and finest looking treasures, only to find that the rain had washed the outer leaves clean and stuck the others together in a tight mass that "broke short off in square bits like a biscuit" when he attempted to open them. But the quest does not end here; we will return to $\mathrm{Mt}$. Athos later.

At this point we have perhaps been refreshed with pride as we recall the sense of excitement and urgency with which men sought for books and built great scholarly libraries in Athens and Alexandria and Renaissance Italy. A similar spirit was at work in eighteenth century America, another era of remarkable intellectual fertility and optimism. Thomas Jefferson's passion for well-ordered scholarly libraries is too well known to require much discussion with this audience; I merely remind you that he stands directly in the tradition we have been discussing. Like Aristotle he built his own library, and not once but thrice, and he bequeathed one to the people of Virginia with a school as Aristotle bequeathed his with a school to Theophrastus.

As Lawrence Wroth put it: "The Library of Congress was founded upon the activities of a book collector, or perhaps we should say a library builder, for Thomas Jefferson-book buyer, friend of learning, and studious devourer of books - had little about him of the bibliomane, the amateur. $\mathrm{He}$ wanted the best, fullest, and most scholarly editions of books in all fields of knowledge. ..." In another age he might well have been one of the long line of scholarly Alexandrian librarians or the founder of a Medicean or Vatican library. Here he meticulously established a university library at Charlottesville and, most importantly, as you all know, in the spring of 1815 he carefully packed 6,487 volumes into ten horse-drawn wagons for delivery from Monticello to the District of Columbia.

We all know this story, but we often forget, I think, what a dramatic and significant event it was. For it is true that the Library of Congress was founded upon Jefferson's library, even though it had been in existence de jure for some years before 1815 . The plain fact is that both the Congress and the American people had been almost unaware of the Library's existence until the British burned it in 1814. Thereupon, as Paul Angle says, "The American people sud- 
denly saw it as an object of national pride, even an ornament to the world's culture."

This curious twist of fate has something of a modern parallel in the recent experience of the University of Texas library. The spring 1959 issue of the British quarterly The Book Collector reports in an editorial note that: "For many years the [Texas] University's rare book department has made no major acquisitions and has rested on the laurels of its Wrenn, Aitken, and Stark collections. But now, fortified and spurred on with greatly increased purchasing power, it enters the field with the expressed intention of outstripping its rivals." The note goes on to describe briefly some, and only some, of the striking collast two years. It is a major story in modern scholarly library development, but although The Book Collector implies әч that Texas was "fortified" with oil millions, it fails to mention what suddenly "spurred" the University onwards. I think the story is clear. In 1957 Yale University Library by a remarkable coup de hasard bought right out from under Texas' nose, right out of the Alamo as it were, Thomas W. Streeter's unsurpassed collection of Texana, for which a five-volume bibliography is now in process of publication. The implications are obvious: Texas pride was suddenly touched with a book; Texans suddenly saw their university library as an object of national pride. I only wish I could have some equally bad luck.

And so it was that by a bit of bad luck in 1814 American pride came to the fore and Congress, after protracted debate and "by a narrow squeak" of ten votes, appropriated $\$ 23,950$ to purchase the finest collection of books in the country, thus setting up the Library of Congress as a serious scholarly library, temporarily housed in a third-floor room in Blodget's Hotel. Part of the protracted debate is instructive. To some the cost was fright- ening; to some the extent and variety of the collection seemed far beyond the needs of the Congress; some proposed to remove all books in foreign languages since they would be of little use; some moved to return to $\mathrm{Mr}$. Jefferson all books "of an atheistical, irreligious, and immoral tendency [such as] the works of the French philosophers, who caused and influenced the volcano of the French revolution." It is always this way. The easy method for building a scholarly library is to buy just those books for which the average working scholar of today can foresee a practical need. It takes imagination and courage and a free hand to make the great strikes that build a library which will stand the test of the future as well as the test of the present. The small-minded economisers and censors are always ready to oppose the purchase of Thomas Jefferson's library.

The impetus of that first great purchase was not lost, for the Library of Congress continued to flourish, except perhaps in recent cautious years. In 1867 Librarian Ainsworth Spofford made an eloquent and successful plea to Congress for a special appropriation of $\$ 100,000$ to buy the "noble library" of Peter Force, the foremost collector and editor of American historical material. Numbering some 60,000 items, this collection made the Library of Congress in one move a major center for books relating to America. Librarian Spofford was shrewd enough to base his plea partly on the fact that the British Museum collections in this field had been superior to any in the United States.

But it is Herbert Putnam, Librarian of Congress from 1899 to 1939 - and you will recall that he got his library start right here in Minneapolis-who stands as one of the great scholarly library builders of all time. I think many of us fail to recognize his stature; a full reading of his annual reports could give us all heart as well as pointers on building a scholarly library. Tonight we can 
mention only a few of his colorful attacks on the book market; some of these stories deserve to be told in greater detail.

In 1901, when Putnam made a careful survey of the collections, he found 569 Russian books on hand. Two years later, in the autumn of 1903, the Library of Congress Slavic specialist, Alexis V. Babine, visited a private library housed in a large, two-story log structure in Krasnoarsk, near Lake Baikal in eastern Siberia. In his description of the library published in 1905, Babine claimed it had "no equal among private libraries . . . in Russia or in any other country." This was the library of Gennadii Vasil'evitch Yudin, a wealthy and widely traveled liquor merchant, who found in his books and studies, "the needed rest from worldly squabbles and a delight which is hard to express." Isolated as he was from the book markets-Krasnoarsk is over 3,000 miles from what was then called St. Petersburg-Yudin had accumulated about 80,000 volumes relating to Russia and Siberia, most of them in Russian, and half a million pieces of manuscript. Babine found the books, in their separate building twice as large as the Yudin residence, overflowing the shelves and piled on the tables and floor.

Librarian Putnam's negotiations moved rapidly under these difficult circumstances. During the winter of 190607 Babine was back in Siberia to spend three months supervising the packing of the books into 500 crates. The Russian government cooperated willingly to the point of clearing the railway lines across Siberia so that the shipment could move westward via Hamburg, whence it reached the Library of Congress in April 1907. The Yudin collection was a solid scholarly library in itself, rich in complete sets of literary and historical journals, archival sets, and newspapers, many of them Siberian. "By one strike," one commentator concludes, "the Library had made itself the possessor of the largest, best balanced Russian library outside Russia itself." The collection was so extensive and uncommon that Lenin is reported to have written, after a visit there, ". . . it is a remarkable collection of books. For instance, there are complete sets of periodicals (the principal ones) dating from the end of the eighteenth century up to the present day and I hope I shall be able to use them for the references necessary for my work ..."And all of these books (most of the manuscripts did not come to the United States) were purchased for a mere $\$ 40,000$, so that the collection was in fact, as Putnam says, "primarily a gift" from Yudin.

Now consider for a moment what this transaction meant and what it means today. The Russo-Japanese war occurred in 1904-05, just as the Putnam-Yudin negotiations were proceeding. To be sure this event may have helped trigger Putnam's action, although it must have complicated transactions with so distant and isolated a place. But how many scholars in that day really foresaw the urgent need for intensive Slavica collections in the United States? The true value of Putnam's investment and Yudin's gift did not appear until after Putnam's retirement. This was an act of powerful and farsighted library statesmanship, and this is how to build a scholarly library.

Another Putnam coup has been, unfortunately, less thoroughly documented. This is a tale that your Deans Blegen and McDiarmid might describe as "the singular and notable affair of Dr. Otto Vollbehr and his books, a story for which the world is not yet prepared." Unlike Sherlock Holmes's untold tales, however, a report of the Vollbehr case is not "safely on file in that famous dispatch box in the vaults of Cox's bank at Charing-Cross." Even the Library of Congress archives, I fear, are inadequate. 
A few facts and some inferences are worth repeating.

The mysterious Dr. Vollbehr appeared on the American scene in the late 1920's with a collection of about 3,000 incunables and a 42-Line Gutenberg Bible on vellum. He is described as "not by vocation a dealer in books, but a retired scientist, who after an accident, had been exhorted to take up 'collecting' as a diversion." Little is known about his collecting, but something is known about his dispersing, because his not too subtle efforts in America all related to "a noble desire to locate his collection in the United States," even though, since it was said to represent an investment of much of his fortune, he could not make an outright gift. With much pomp and ceremony the Vollbehr treasures, and they were indeed treasures, were displayed in various likely locations, and even in so unlikely a locality as Kansas. The Kansas episode alone has touches of a Graham Greene "entertainment." But these were curious times: the United States economy was in an unsettled state and so was German politics; both were apparently significant factors in l'affaire Vollbehr.

Somewhere along the way, it is reported, Dr. Vollbehr "conceived the idea ... . that some American citizen might contribute one-half the commercial value of it (which he then without the Bible reckoned at $\$ 3,000,000)$; in which case he professed willingness to forego the remaining half." For nearly two years this elusive citizen was pursued, but in the fall of 1929 there seemed no point in looking further and a report was circulated that the collection was due to return to Europe for sale at auction.

At this point Representative Collins of Mississippi appeared on the scene, with a remarkable amount of "public opinion" behind him, to the point where Congress in an unparalleled cultural effort appropriated $\$ 1,500,000$ to buy the Vollbehr collection for the people of the
United States. Dr. Vollbehr magnanimously accepted the U.S. Government as partner in the donation, and the books came to the Library of Congress "subject only to release of certain claims against Dr. Vollbehr which constituted a lien against them." It is truly a remarkable story in the history of research library growth. One wishes one knew more about librarian Putnam's cautious and cool maneuvering behind the legislative scenes as well as more about the intricate relationships-financial, political, and social_of Dr. Vollbehr.

But despite the mystery and the maneuvering, the Library of Congress and Putnam came off well, for this at once put the Library of Congress in the front rank among American libraries holding STC books, exceeded only by the Huntington; it was reported that 40 per cent of the Vollbehr books were not recorded elsewhere in the United States. Altogether a stunning development for the Library of a Congress that too frequently has failed to see its Library as a truly national research center. Coupled with the more recent, more generous, and choicer gift of Mr. Lessing Rosenwald, this puts the Library firmly among the great scholarly rare book collections in this country.

Again, one senses a more recent parallel, in the case of a well-known-should one say "notorious"?-New Orleans classical library, long peddled around the country by a collector who perhaps unwittingly saw himself as a latter-day Vollbehr. But this story, too, must be left discreetly in a locked dispatch box, said now to be in Texas, until the library's new owner sees fit to release the story to an eager world.

But all of this, from Poggio to Vollbehr, may seem somewhat off the track. We have talked thus far about scholarly libraries of various sorts, from personal to national ones, but little about university libraries, especially those of our own type and time. But is there any essential 
difference? I think not. The great university libraries in this country have been built in similar style, with gusto and with imagination, by librarians, by faculty, and even by university presidents who have followed in this same tradition of the great library builders of the past.

We all know something of the librarians, in our generation and earlier, who will be remembered for their nose for books. And we are all grateful for the occasional faculty member who reads book catalogs rather than mystery stories. But since we must be selective and cursory this evening, let us consider another, often overlooked, group of library builders-university presidents. This might be a rewarding venture at a time when we hear too much about those few shortsighted presidents who find their scapegoat in the book stacks.

But first let me interject a cranky comment on this whole matter of fear about excessive library growth. I cannot help recalling the sense of pride and optimism with which Demetrius of Phalerum and his King proposed to increase the Alexandrian Library holdings from two hundred thousand to half a million. There was no sense of impending doom, and you will recall that the problems of housing and cataloging the kinds of books in that library far exceeded those which we face. Why suddenly have we reached the saturation point? I read again only recently that the modern university cannot countenance or finance the continually increasing demands for library space and money. Yet I wonder whether the space and money demanded for medical education is rising at any lesser rate? I think not; yet in the face of that increase we call urgently for more and larger and better medical schools, and the federal government and the foundations hasten to help. I know of universities, good ones, where in very recent years major basketball stadia have been declared obsolete and new ones, many times the size of the campus library, have been erected with enthusiasm. The cost and space required for married student housing is being met somehow, and the need will only increase, but no one says this is the end. I certainly don't deplore these other aspects of higher education, but I do say that universities can finance what they think is important. The recent distress about library growth is a sad commentary indeed on our sense of values in higher education.

But enough of this; let us look again at the historical record and take heart, for there have been, and still are, university administrators who collect books and build scholarly libraries without stint and with the same missionary zeal that we met in Demetrius and his King, Poggio and the Medicis, Thomas Jefferson and the builders of the Library of Congress.

In a sense Thomas Jefferson belongs also in this camp, of the presidents and founders of universities, but we are aware of his activities and can therefore turn to one who is perhaps less well known and who may be the greatest of them all, Andrew Dickson White, the first president of Cornell University. He is the classical type. His two-volume Autobiography should be required reading for all university presidents, librarians, and regents, and his book collecting, personal and institutional, deserves fuller treatment than it has as yet received.

Throughout his whole career books were an intimate and essential passion which, he concluded, "added certainly to the pleasures, and probably to the usefulness, of my life." Andrew Dickson White's boyhood memories relate to the books he read. As an old man reminiscing about the beginnings of his private library during college days, he had this to say: "Books which are now costly 
rarities could then be bought in the European capitals for petty sums. There is hardly any European city which has not been, at some time, one of my happy hunting-grounds in the chase for rare books bearing upon history; even now, when my collection, of which the greater part has been transferred to Cornell University, numbers not far short of 40,000 volumes, the old passion still flames up at times." In fact, he confesses, he had just recently fallen before the lure of two series of early manuscripts.

This flaming passion led Andrew Dickson White to accumulate at least two superb scholarly personal libraries in the midst of a tremendously busy life. His architectural library was of such quality that he made an agreement with the Cornell trustees, whereby he would give it to them if they would establish a department of architecture and endow a professorship. At the same time, he went on collecting historical literature with such vigor that in 1855 , when he left the presidency and turned the library over to Cornell, he could call it "one of the largest, and, in its field, one of the best private collections of books in the United States."

Moreover no one could say that he was a bemused amateur uncertain of the needs of a scholarly library, for White came to Cornell after a successful professorship at Michigan, and he continued teaching for many years after the founding of Cornell. He had definite ideas about the utility of books and manuscripts in the teaching process, and they were imaginative and generous ideas that give the lie to the so-called practical scholar who despises original editions and manuscripts, while asserting that a good edited text is all that one needs. White had discovered early in his teaching days, "that passages actually read from important originals during my lectures gave a reality and vividness to my instruction which were otherwise unobtainable. . . No rhetoric could impress on a class the real spirit and strength of the Middle Ages as could one of my illuminated psalters or missals ... [and] all specifications of the folly of Marat paled before the ravings in the original copies of his newspaper, L'Ami du Peuple."

Given this personal and professional passion for books and this knowledge of how to build and use a personal scholarly library, it is clear that as a pioneering university president Andrew Dickson White would, give equivalent emphasis to the Cornell Library. He was only bullish about library growth. Looking back over the early developments of the Cornell Library he exulted late in his life: "There often come back vividly to me remembrances of my college days, when I was wont to enter the Yale Library and stand amazed in the midst of the sixty thousand volumes which had been brought together during one hundred and fifty years. They filled me with awe. But Cornell University has now, within forty years from its foundation, accumulated very nearly three hundred thousand volumes, many of them of far greater value than anything contained in the Yale library of my day." This was a proud boast, no dour despair over the quintupling of a collection. Are we to think then that today he would be searching for ways to limit the size of Cornell's library of two million volumes? I doubt it. In fact I think he might rather have been disheartened by the temporary decline in the library's fortunes some years after his death; and I can imagine his delight at its more recent recovery and especially at the news that the Rockefeller Foundation has just granted Cornell $\$ 75,000$ for the acquisition of research library materials on Southeast Asia.

One of his first acts as president of Cornell was to spend time in Europe buying books for the new university, and throughout his presidency he gave the library his personal attention. Here is 
an illuminating story of both President White and Mr. Ezra Cornell: "Having found, in the catalogue of a London bookseller, a set of Piranesi's great work on the Antiquities of Rome-a superb copy, the gift of a pope to a royal duke -I showed it to [Mr. Cornell], when he at once ordered it for our library at a cost of about a thousand dollars."

On another occasion he recalled the great difficulty of getting Latin and Greek firmly established in the Cornell curriculum: "But an opportunity now arose for clinching it into our system. There was offered for sale the library of Professor Charles Anthon of Columbia, probably the largest and best collection in classical philology which had then been brought together in the United States. Discussing the situation with Mr. Cornell, I showed him the danger of restricting the institution to purely scientific and technical studies, and of thus departing from the university ideal. He saw the point, and purchased the Anthon library for us. Thenceforth it was felt that, with such a means of instruction, from such a source, the classical department thus would stand firm; that it must on no account be sacrificed; that, by accepting this gift, we had pledged ourselves to maintain it." Here then is a dramatic picture of how to build a scholarly library and why it is of such great consequence in the life of a university. Here also is a practical commentary on the cautious thesis that a library's acquisition program should be based on the clear needs of the present faculty. More significant, in my judgment, is the tendency for the staff of a university to be shaped by the holdings of the library. A clear lesson from the great library builders is that imaginative foresight is essential.

It may well be that in Andrew Dickson White we have the classical example of the university administrator as a collector, but he is by no means entirely alone. William Rainey Harper, as the founding president of another great university, gave Chicago the right early emphasis. Like White, one of Harper's initial acts as president was a trip to Europe to acquire, among other things, library books. In this regard he had surpassing success. Soon after settling in Berlin, according to his biographer, Harper secured "an option for the purchase by the University of the Calvary library, a collection of more than 200,000 books, manuscripts, and pamphlets." On his return to Chicago Harper raised from friends the purchase price of $\$ 45,000$. Later called the "Berlin" collection, this remarkable coup got the University of Chicago library off to the right start, and as the present librarian points out, "Harper had the nerve to go out and buy this huge collection before he had any place to put it or indeed a staff to organize it." This colorful episode in university history should be required reading for the many timid librarians and presidents who boggle at bulk purchases when library shelves are clogged and staffs behind in their work. Harper, like White, was also a distinguished scholar, whose Semitic library came to the University on his death. One only wonders what other great services William Rainey Harper would have rendered if he had not died painfully at the peak of his career.

Yet some may say that White and Harper are eccentrics since they are both founding presidents and of another generation. But the hopeful fact is that today, in the face of much pessimism, we have a flowering of administrative officers with a flair and a passion for building scholarly libraries. I am convinced that their universities will flourish. Let me merely point to Vice-President and Provost Gordon Ray of Illinois, a leading Thackeray scholar and a skilled book buyer, who spends his summers with a marked $C B E L$ in hand, sweeping up books for Illinois. His story of the purchase of the Tom Turner library for 
Illinois in the winter 1953 issue of The Book Collector deserves a place in our anthology. His opposite number at Texas, Harry H. Ransom, is personally responsible for the sudden renaissance of his university library. On top of other vigorous administrative duties, he has swept into Austin the Hanley, Parsons, Ellery Queen, and other famous collections during the past two years. While gaping with admiration at these truly Texan ventures, one may still have some qualms about certain of the purchases and some of the administrative procedures apparently involved. These men too are in the direct tradition of Poggio and Curzon as well as of Jefferson and Andrew Dickson White. So long as their kind shall fluorish, and I see no reason to believe that the end has come, scholarly libraries will continue to be built with enthusiasm and vigor.

And, to be sure, they are still being built in this spirit. Let me remind you of only three great strikes of the past few years: Yale's acquisition of the Streeter collection of Texana has been mentioned; one of the finest reports of its kind in library literature is of Michigan's dramatic purchase of the Stellfeld musicology collection from Belgium, in the December 1954 issue of the Music Library Association's journal Notes; a third, Berkeley's purchase in 1950 of the 100,000-volume Mitsui library from Tokyo, deserves equivalent public reporting, but again we are told "the world is not yet prepared" for the story. We can rejoice also in the recent mushrooming of distinguished rare book collections at Indiana and Minnesota, the result in our day of magnanimous bequests of a kind that pessimists a decade ago said would never again occur in American society. In the face of this there are still those who would suggest that the great opportunities of the past are gone. Obviously this is not so. I would point only to Cornell's recent imaginative and romantic proposal to microfilm "a collection of manuscripts held by the Sultan of Djakarta in Indonesia, many of which may never have been seen before by western scholars." And I would report to you that the enterprising Royal Librarian of Sweden is now on his way to Peking to repay a visit from his opposite number of China, whereas the stupidly shortsighted American official censorship prevents our federal libraries from even corresponding with Red China. There are indeed opportunities, given imagination and a free hand. There is also, and still, Mt. Athos, as we will soon see.

If we had more time this evening I would conclude this anecdotal discussion with some fuller account of a giant among scholarly library builders, a man whose career should be studied carefully by all librarians. Hubert Howe Bancroft of California's pioneering days successfully compiled, edited, and published historical studies, amounting to over thirty volumes in all, on a factory basis, long before the days of organized group research; and he swept together the Bancroft library with the same overwhelming gusto and on the same mass basis. He hauled in wagonloads of newspapers in the 1860 's, long before accred-. ited historians recognized them as source material; he sent out his agents to copy archival documents, long before microfilming; he hired reporters to take down the recollections of pioneers, long before oral history projects were fashionable. He scoured the book markets of the East and of Europe and bought up libraries wholesale. "His policy was, when in doubt, to buy; he thought it cheaper than to waste time examining an item with extra thoroughness and debating with himself whether it should be included. That many an item thus acquired was practically worthless never bothered him at all, because he was convinced that completeness was the high- 
est desideratum in a collection and that the most insignificant item when made part of a larger family would prove of value, perhaps of sizeable value."

We are fortunate in having a close estimate of Bancroft's services to scholarship and collecting in Professor John Walton Caughey's Hubert Howe Bancroft, Historian of the West (Berkeley, 1946), from which I have just quoted. In this study, Professor Caughey offers the most cogent and sympathetic analysis I have seen of the qualities and procedures that go into building a research library: an omnivorous, diligent, and ingenious delight in ferreting out material; the foresight and a willingness to go beyond the posted boundaries of scholarship; a flair for opportunistic attack rather than blind dependence on a preconceived plan; the courage to spurn selectivity in favor of the mass approach; and basic to all of this, imagination of a high order and a free hand to put it to use. This is my reading of Professor Caughey's analysis, and to it I can only say "Amen." The book market I have been discussing is keenly competitive, and the competition increases with the establishment of new universities all across the country, with the invigorated growth of the West German university libraries, and with the ambitious acquisitions programs of Russian libraries. It behooves us to move rapidly and opportunistically if we are to retain initiative in the world book market.

The best expression of Bancroft's theory and technique of collecting is of course the unsurpassed Bancroft library of over 60,000 items which was evaluated in 1905 by Reuben Gold Thwaites, a name well known to the proud possessors of the James Ford Bell collection, as "an astonishingly large and complete [library], easily first in its own field," and worth at least $\$ 315,000$. Suffice it to say that the president and regents of the youthful University of California took a deep breath and committed themselves to a purchase amounting to "30 per cent of the annual amount for instruction at Berkeley." But this courageous and bullish investment was a wise one. In about ten years, according to Professor Caughey, the Berkeley history department concerned with Western and Spanish-American studies became "the most distinguished in the United States," and the Bancroft Library continues half a century later to be a crown jewel. This is without doubt one of the most striking examples of how to build a scholarly library.

Well, it is time to come full circle, and the circle is neatly closed by an exciting but small pamphlet with the drab and official title of: $A$ Descriptive Checklist of Selected Manuscripts in the Monasteries of Mount Athos Microfilmed for the Library of Congress . . 1952-53 (Library of Congress, 1957). The introduction to this small publication describes how in a six months period during 1952 53 a team of scholars sent out from the Library of Congress "microfilmed 209 Greek and Georgian Biblical manuscripts in full and selected portions of 44 others ... ranging in age from the sixth to the fifteenth centuries." This project was undertaken because scholars today are aware that despite the efforts of Lascaris and Curzon, "The twenty ruling monasteries of Mount Athos in Macedonia house a manuscript collection of staggering proportions, estimated to number about 11,000 books which represent the vast learning of the ages of Athens and Byzantium." On foot and on muleback, these modern scholars, equipped with microfilming equipment, followed in the footsteps of their predecessors. Yet despite the microfilm, the world seems to have changed but little in the intervening centuries. Dr. Saunders recalls that, "The room to which we were directed looked down upon the 
rocky cliffs several hundred feet below lashed by a snarling March sea. Our uneasiness was not put to rest when we learned from our genial young host that the foundations [of the monastery] had been seriously weakened by an earthquake. ..."At Stavroniketa they found another situation reminiscent of Curzon, with the library "located in a dark and damp room on the courtyard level and the mildewed books ... sadly disarranged." Fortunately libraries in some of the other monasteries were in somewhat better condition. Despite modern technical equipment, there were pioneering difficulties: "At night, the test strips were developed and examined carefully by flickering kerosene or candle light."

Thus in the middle of the twentieth century we come once again full circle to the very spirit and the very haunts of the Alexandrian librarians, of Poggio Bracciolini and John Lascaris, and of Robert Curzon. The quest continues; there is no end. Hallelujah!

\section{ARL Washington Meeting}

The fifty-third meeting of the Association of Research Libraries was held on June 21 at the Library of Congress. At the afternoon session the major topic was the role of research libraries in supporting the expanding scientific research and development program in the United States. Discussion was based on a working paper prepared by Burton W. Adkinson, head of the Office of Science Information Service of the National Science Foundation. Emphasis was placed on the responsibility of research libraries for acquiring foreign scientific and technical publications, and for the proper bibliographical control of them. At the evening session, attention was devoted to such topics as the organization of the Farmington Plan, the studying of the legal aspects of "fair use in photocopying," and bibliographic control of microreproductions. Two other matters discussed included devising a system for obtaining prompt and extensive coverage of Washington news and activities of interest to ARL members (Stephen A. McCarthy of Cornell will attempt to coordinate information), and the disintegration of scholarly materials. In respect to the latter item, members passed the following resolution:

"The Association of Research Libraries notes in a recently published study on paper deterioration [W. J. Barrow and R. C. Sproull, 'Permanence in Book Papers,' Science, CXXIX (1959), 1075-84] that a very high percentage of contemporary books and periodicals is being printed on papers that are likely to be highly impermanent, and that the techniques in the paper manufacturing process for correcting such deterioration appear to be relatively simple and inexpensive. Therefore the Association wishes to record its deep concern with the correction of this situation, and instructs its Executive Secretary to take such steps as may seem appropriate to bring this matter to the attention of book and periodical publishers, learned societies, and others. It is obvious that the continued addition to research libraries of books on deteriorating paper will add enormously to the future costs of research library operation and will also certainly impair the ease of future access to scholarly information." 